\title{
Influences of Hydraulic Fracturing on Fluid Flow and Mineralization at the Vein-Type Tungsten Deposits in Southern China
}

\author{
Xiangchong Liu, ${ }^{1,2}$ Huilin Xing, ${ }^{3}$ and Dehui Zhang ${ }^{4}$ \\ ${ }^{1}$ Institute of Geomechanics, Chinese Academy of Geological Sciences, Beijing 100081, China \\ ${ }^{2}$ The Laboratory of Dynamic Digenesis and Metallogenesis, Institute of Geomechanics, CAGS, Beijing 100081, China \\ ${ }^{3}$ Centre for Geoscience Computing, School of Earth and Environmental Sciences, The University of Queensland, \\ Brisbane, QLD 4072, Australia \\ ${ }^{4}$ State Key Laboratory of Geological Processes and Mineral Resources, School of Earth Sciences and Resources, \\ China University of Geosciences (Beijing), Beijing 100083, China
}

Correspondence should be addressed to Dehui Zhang; dehuizh@cugb.edu.cn

Received 10 February 2017; Revised 17 May 2017; Accepted 1 June 2017; Published 24 July 2017

Academic Editor: Xing Ding

Copyright (C) 2017 Xiangchong Liu et al. This is an open access article distributed under the Creative Commons Attribution License, which permits unrestricted use, distribution, and reproduction in any medium, provided the original work is properly cited.

\begin{abstract}
Wolframite is the main ore mineral at the vein-type tungsten deposits in the Nanling Range, which is a world-class tungsten province. It is disputed how wolframite is precipitated at these deposits and no one has yet studied the links of the mechanical processes to fluid flow and mineralization. Finite element-based numerical experiments are used to investigate the influences of a hydraulic fracturing process on fluid flow and solubility of $\mathrm{CO}_{2}$ and quartz. The fluids are aqueous $\mathrm{NaCl}$ solutions and fluid pressure is the only variable controlling solubility of $\mathrm{CO}_{2}$ and quartz in the numerical experiments. Significant fluctuations of fluid pressure and high-velocity hydrothermal pulse are found once rock is fractured by high-pressure fluids. The fluid pressure drop induced by hydraulic fracturing could cause a $9 \%$ decrease of quartz solubility. This amount of quartz deposition may not cause a significant decrease in rock permeability. The fluid pressure decrease after hydraulic fracturing also reduces solubility of $\mathrm{CO}_{2}$ by $36 \%$ and increases $\mathrm{pH}$. Because an increase in $\mathrm{pH}$ would cause a major decrease in solubility of tungsten, the fluid pressure drop accompanying a hydraulic fracturing process facilitates wolframite precipitation. Our numerical experiments provide insight into the mechanisms precipitating wolframite at the tungsten deposits in the Nanling Range as well as other metals whose solubility is strongly dependent on $\mathrm{pH}$.
\end{abstract}

\section{Introduction}

The Nanling Range in southern China is a world-class tungsten province [1]. Wolframite is the main ore mineral at the vein-type tungsten deposits in this area [2]. One disputed issue on the ore forming processes is how wolframite is precipitated. Three mechanisms have been proposed from fluid inclusion and stable isotopic analysis to cause wolframite deposition: fluid mixing, simple cooling, and fluid immiscibility [3-11]. However, the formation of magmatichydrothermal deposits involves complicated mechanical and chemical processes [12-14]. Previous work does not consider the links of mechanical processes to ore formation.
Fracturing wallrock driven by high-pressure fluids from magma increases the permeability and promotes heat and solute transport [15-20]. These mechanical processes also promote chemical disequilibrium of hydrothermal systems and control ore deposition [21, 22]. For the tungsten deposits in the Nanling Range, fluid inclusions record the fluid pressure fluctuations caused by hydraulic fracturing $[5,6,23$, 24]. Therefore, understanding hydraulic fracturing may shed some light on wolframite deposition.

This study is organized into three parts. We first introduce the geological background of the vein-type tungsten deposits in the Nanling Range. Based on the geological and geochemical characteristics, then establish a numerical model and 

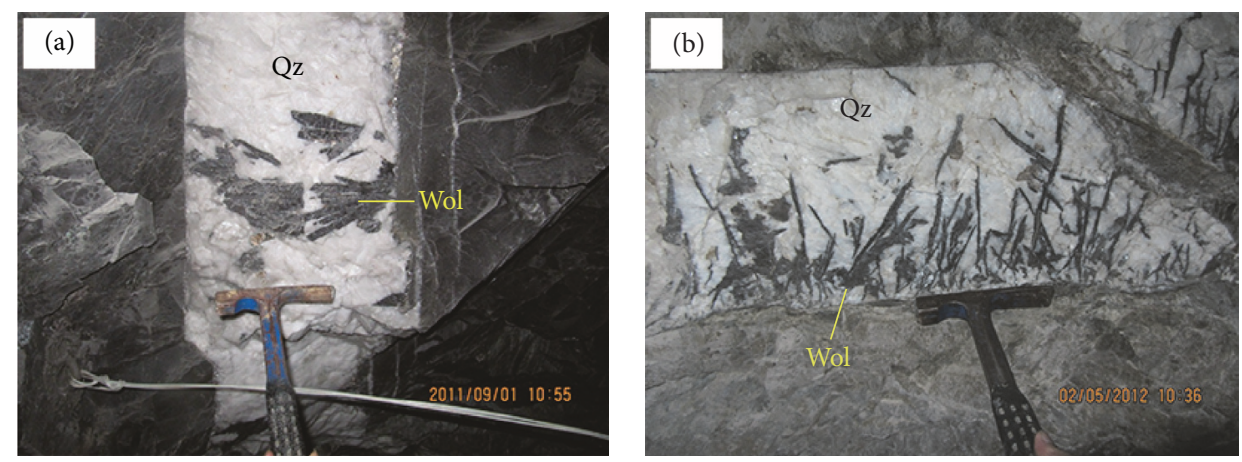

FIGURE 1: Photos of wolframite-quartz veins at two tungsten deposits in the Nanling Range. (a) Tabular wolframite has grown symmetrically normal to the walls of a thick vein at the Dajishan deposit [28]. View to upwards. (b) Needle-like wolframite crystallizes normal to the wallrock at the Piaotang deposit. View to upwards. Qz, quartz; Wol, wolframite.

investigate the influences of a hydraulic fracturing process on fluid flow and solubility of carbon dioxide $\left(\mathrm{CO}_{2}\right)$ and quartz. Finally, we discuss the influences of the hydraulic fracturing process on hydrothermal flow and tungsten mineralization.

\section{Geological Background of the Tungsten Deposits in the Nanling Range}

The vein-type tungsten deposits in the Nanling Range are dated at an age range of 160 150 Ma and genetically related to continental crust remelting type granitoids during the Jurassic to Cretaceous $\left(\mathrm{J}_{2}-\mathrm{K}_{2}\right)[1,25,26]$. The mineralized veins are present nearby the roof zone of buried alkalifeldspar granite and extend a depth of 1000 metres [27]. Wolframite is the main ore mineral in the veins (Figure 1) and the gangue minerals have quartz, feldspar, muscovite, calcite, and tourmaline [2].

Hydrogen, oxygen, carbon, and sulfur isotopic data indicate that the ore fluids have a magmatic origin at the main mineralization stage and then were mixed with meteoric waters at late stages [29]. The mineralized fluids are $\mathrm{NaCl}$ $\mathrm{H}_{2} \mathrm{O} \pm \mathrm{CO}_{2}$ systems with a small amount of $\mathrm{CO}, \mathrm{CH}_{4}, \mathrm{~N}_{2}$, and $\mathrm{H}_{2}$. The fluid inclusions trapped by ore and gauge minerals have homogenization temperatures from $160^{\circ} \mathrm{C}$ to $390^{\circ} \mathrm{C}$ and salinities from 1 to $10 \mathrm{wt} . \% \mathrm{NaCl}$ equivalent. The mineralization pressures recorded by fluid inclusions have a range within 20 160 MPa with maximum range of 75 160 MPa [3, $5,6,9,10,23,24,30-32]$. Silicate melt inclusions in wolframite and beryl have a homogenization temperature up to $700^{\circ} \mathrm{C}$ and a homogenization pressure of 160 200 MPa [33].

Previous structural analysis of vein arrays at tungsten deposits in the Nanling Range suggests that high-pressure fluids trigger fracture initiation and propagation [34-36]. The high-pressure fluids and the pressure fluctuations are also recorded by fluid inclusions [5, 6, 23, 24]. Polya [37] proposes that a pressure decrease after hydraulic fracturing causes wolframite precipitation from hydrothermal solutions for two reasons. One reason is that wolframite solubility is pressure-dependent. This reason is concluded from quantitative solubility calculations. The other reason derived from qualitative analysis is that dramatic decrease in fluid pressure may cause $\mathrm{H}_{2} \mathrm{O}-\mathrm{CO}_{2}$ immiscibility and increase $\mathrm{pH}$. The thermodynamic model developed by Wood and Samson [38] suggests that wolframite solubility is only weakly dependent on pressure; therefore, Wood and Samson's model contradicts Polya's first reason. Wood and Samson's model supports that $\mathrm{CO}_{2}$ loss decreases tungsten solubility because tungsten solubility is strongly dependent on $\mathrm{pH}$, but they do not consider the influence of pressure drop on $\mathrm{CO}_{2}$ solubility and further impact on tungsten solubility. Therefore, it is necessary to check the links of the pressure drop after hydraulic fracturing to $\mathrm{CO}_{2}$ solubility. In the next sections, finite element-based numerical experiments are used to quantify the influence of a hydraulic fracturing process on fluid flow and solubility of $\mathrm{CO}_{2}$ and quartz.

\section{Numerical Modelling of Tungsten Deposits in the Nanling Range}

3.1. Hydromechanical Theories. The mechanics of hydraulic fracturing is first synthesized by Hubbert and Willis [39] using the concept of effective stress. The technique of artificial hydraulic fracturing has been successfully developed to increase oil and gas reservoir production; therefore, most of our knowledge about hydraulic fracturing comes from those fields [40-42].

Hydraulic fracturing is a fluid-to-solid coupling where a change in fluid pressure or fluid mass alters the volume of a porous material and produces strains [43]. Several conceptual models have been proposed to understand how hydraulic fracturing involves formation of hydrothermal veins [4449]. There are also numerous numerical models developed to clarify hydraulic fracturing and further hydrothermal flow in magmatic-hydrothermal systems [12, 13, 16, 19, 50-56]. However, many of those models do not solve the constitutive relation of rock deformation; therefore, the hydraulic fracturing processes are not well captured.

The coupling of rock deformation and fluid flow in this study is governed by poroelastic constitutive equations, continuity equation, and Darcy's law [57]. These simultaneous partial differential equations are solved by PANDAS. PANDAS is a finite element-based supercomputer simulator 
and has been applied to study the coupled hydraulic-thermalmechanical behaviours in active fault systems, geothermal reservoirs, and ore formation [28, 58-65].

Various yield criteria are implanted in PANDAS including the Maximum Tensile Stress Criterion and the DruckerPrager Criterion [66] used in this paper. The three principle stresses $\sigma_{1}, \sigma_{2}, \sigma_{3}$ satisfy the inequality: $\sigma_{1} \geq \sigma_{2} \geq \sigma_{3}$. Positive normal stresses mean compression and negative normal stresses represent tension. Extensional failure is produced once the tensile minimum principle stress exceeds the uniaxial tensile yield strength. Extensional fracture is normal to $\sigma_{3}$ and aligned with $\sigma_{1}$. Shear fractures are produced when the shear stress reaches the shear strength. Both shear failure and extensional failure form an anisotropic permeability tensor.

3.2. Key Assumptions. The following assumptions were made to conduct numerical experiments at a reasonable computational cost: (1) high temperature did not alter the rock constitutive relation. The deformation regime of rocks changes from brittle to ductile around $400^{\circ} \mathrm{C}$ [21, 67]. A background temperature of $350^{\circ} \mathrm{C}$ was set in the model. It was assumed that this temperature would not alter the deformation regime from brittle to ductile. (2) Hydrothermal fluid flow was driven by a constant pressure. The timescales of abrupt rock deformation like crack initiation are significantly smaller than those of other subsets of ore forming processes [68]. It was assumed that the supply of magmatic fluids maintained the fluid pressure at a constant level. (3) Heat transport was not calculated by the simulator codes because the temperature field would change little during the short timescales of fracturing. (4) The model was set in a deep depth and the fluid flow was single-phase; otherwise, fluid flow may be two-phase in a shallow depth [51].

\subsection{A Two-Dimensional Numerical Model of Tungsten} Deposits in the Nanling Range. A 2D numerical model at a depth of $4 \mathrm{~km}$ was built based on the structural and geochemical characteristics of tungsten deposits in the Nanling Range. This depth was determined from the mineralization pressure of the tungsten deposits (see Section 2). This depth is also the emplacement depth of many typical tungsten-tin and porphyry copper systems elsewhere [15, 19, 69-71]. The model has only one unit with a size of $100 \mathrm{~m} \times 100 \mathrm{~m}$ (Figure 2). $x$-axis represents the orientation normal to veins and $z$-axis is vertical. The rock model was discrete into 39200 elements with 59643 nodes in total (Figure 3). The parts close to the fluid source had much finer meshes than the other parts of the model.

Operation of the numerical experiments had two steps. At the first step, a vertical stress of $100 \mathrm{MPa}$ was loaded at the top and a horizontal stress of $60 \mathrm{MPa}$ was loaded on the left and right sides of the model. The bottom was fixed vertically. Assuming a lithostatic gradient of $25 \mathrm{MPa} / \mathrm{km}$, these boundary conditions formed an initial extensional stress field at a depth of $4 \mathrm{~km}$. At the second step, the loaded stresses at the first step were removed but the displacement boundary conditions were held. At this step, a fluid pressure of $200 \mathrm{MPa}$ was fixed at the bottom to represent the highpressure fluids released from magma at depth. An initial

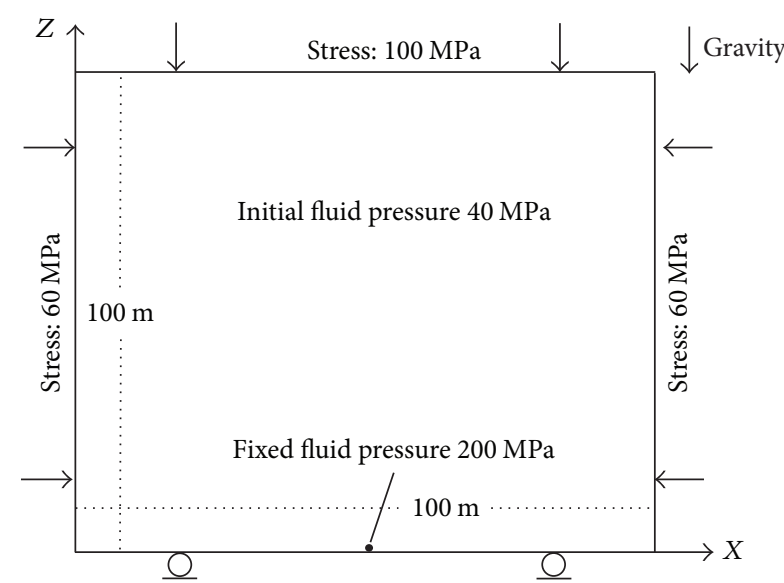

Figure 2: The 2D geometric model in the numerical experiments. The model has a size of $100 \mathrm{~m} \times 100 \mathrm{~m}$. $x$-axis represents the orientation normal to veins and $z$-axis is vertical. How the stress and pressure conditions are operated is shown in Section 3.3.

TABLE 1: Rock mechanical and hydraulic parameters in the numerical experiments.

\begin{tabular}{lc}
\hline Parameters (unit) & Values \\
\hline Porosity $(\%)$ & 0.5 \\
Permeability $\left(\mathrm{m}^{2}\right)$ & $10^{-17}$ \\
Young's modulus $(\mathrm{GPa})$ & 80 \\
Poisson ratio & 0.25 \\
Friction angle $\left(^{\circ}\right)$ & 30 \\
Cohesion $(\mathrm{MPa})$ & 60 \\
Tensile strength $(\mathrm{MPa})$ & 5 \\
Fluid density $\left(\mathrm{kg} / \mathrm{m}^{3}\right)$ & 882 \\
Fluid viscosity $(\mathrm{Pa} \cdot \mathrm{s})$ & $1.5 \times 10^{-4}$ \\
Fluid compressibility $\left(\mathrm{Pa}^{-1}\right)$ & $5.3 \times 10^{-10}$ \\
\hline
\end{tabular}

fluid pressure of $40 \mathrm{MPa}$ was set to form an initial pressure field at the depth of $4 \mathrm{~km}$ assuming a hydrostatic pressure gradient of $10 \mathrm{MPa} / \mathrm{km}$. Table 1 shows the rock's hydraulic and mechanical parameters. The fluid density, viscosity, and compressibility of $\mathrm{NaCl}$ solutions at the temperature of $350^{\circ} \mathrm{C}$ with a salinity of $10 \mathrm{wt} . \% \mathrm{NaCl}$ equivalent were reproduced from the empirical models in $[64,72]$. The mineralized veins at tungsten deposits in the Nanling Range are hosted by metamorphosed sandstone and slate, granite $[73,74]$. The mechanical parameters of sandstone and granite in [75] were used in the model. A reference point was selected to show the evolution of stresses and fluid flow during hydraulic fracturing (Figure 3).

The fluid pressure was the only variable controlling solubility of $\mathrm{CO}_{2}$ and quartz in the model. It is a controversial issue whether the mineralized fluids contain $\mathrm{CO}_{2}$ at tungsten deposits in the Nanling Range. The existence of $\mathrm{CO}_{2}$ is identified in fluid inclusions in gauge minerals like quartz, beryl, and topaz that can reflect the temperature and salinity conditions at an early mineralization stage $[6,10,11,76,77]$. In contrast, the infrared microthermometry of fluid inclusions 

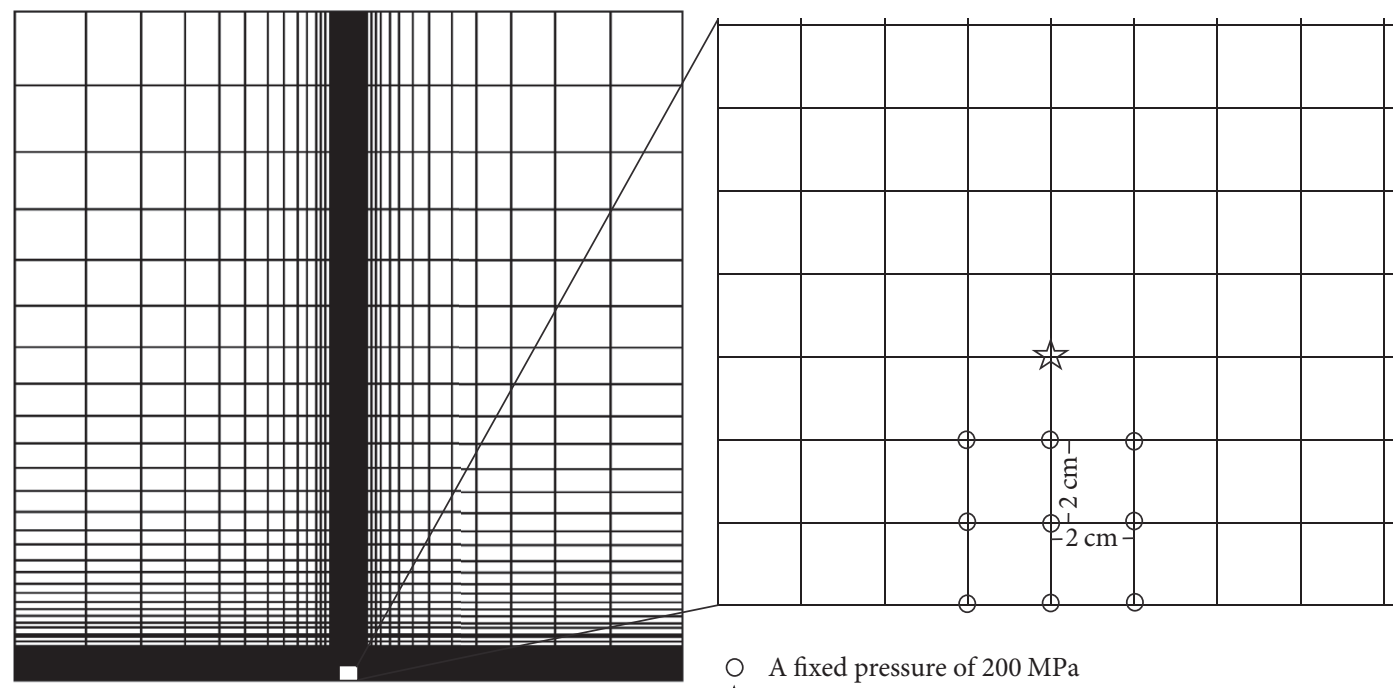

A fixed pressure of $200 \mathrm{MPa}$

点 The reference point

Figure 3: The finite element meshes of the model. The left figure shows the whole meshes in the model. The right figure shows the finer meshes $(2 \mathrm{~cm} \times 2 \mathrm{~cm})$ in the parts close to the fluid source. The reference point is above the nodes where a fluid pressure of $200 \mathrm{MPa}$ is fixed.

in wolframite suggests that the mineralized fluids are $\mathrm{NaCl}-$ $\mathrm{H}_{2} \mathrm{O}$ systems $[3,4,9,11]$. High concentrations of $\mathrm{W}, \mathrm{Mn}$, and $\mathrm{Fe}$ are found in fluid inclusions in quartz [78]. This indicates that the fluid inclusions in quartz have trapped the mineralized fluids at some mineralization stages, although whether the mineralized fluids trapped in quartz are the same with those in wolframite is still enigmatic. Thus, results from fluid inclusions in quartz still have some reference value and $\mathrm{CO}_{2}$ is still considered to be involved in tungsten mineralization as a control of $\mathrm{pH}$.

\section{Results}

The principle stresses $\left(\sigma_{1}, \sigma_{3}\right)$ at the reference point decreased as the high-pressure fluids flew into the host rock (Figure 4). The minimum principle stress $\left(\sigma_{3}\right)$ at the reference point reached the tensile strength after 7.7 seconds when the maximum principle stress $\left(\sigma_{1}=13 \mathrm{MPa}\right)$ was still compressive and the differential stress was $18 \mathrm{MPa}$. In PANDAS, the stresses become zero once they reach the shear or extension strength.

The fluid pressure at the reference point kept increasing and the fluid velocity decreased gradually before yield (Figure 5). The tensile failure increased the permeability of the reference point and caused a sharp decrease of fluid pressure from $168 \mathrm{MPa}$ to $148 \mathrm{MPa}$. The fluid velocity increased significantly to approximately $0.09 \mathrm{~m} / \mathrm{s}$. After that, there were also several smaller fluctuations of fluid pressure and velocity at the reference point because the surrounding nodes were fractured. The fluid pressure decreased to $115 \mathrm{MPa}$ and the fluid velocity increased to $0.004 \mathrm{~m} / \mathrm{s}$ at the last fluctuation.

The solubility model in [79] was used to calculate $\mathrm{CO}_{2}$ solubility in aqueous $\mathrm{NaCl}$ solutions. Because $\mathrm{CO}_{2}$ solubility in aqueous $\mathrm{NaCl}$ solutions increases with fluid pressure at a temperature of $350^{\circ} \mathrm{C}$, the fluid pressure fluctuations during hydraulic fracturing caused a similar change on $\mathrm{CO}_{2}$ solubility (Figure 6). $\mathrm{CO}_{2}$ solubility at the reference point reached

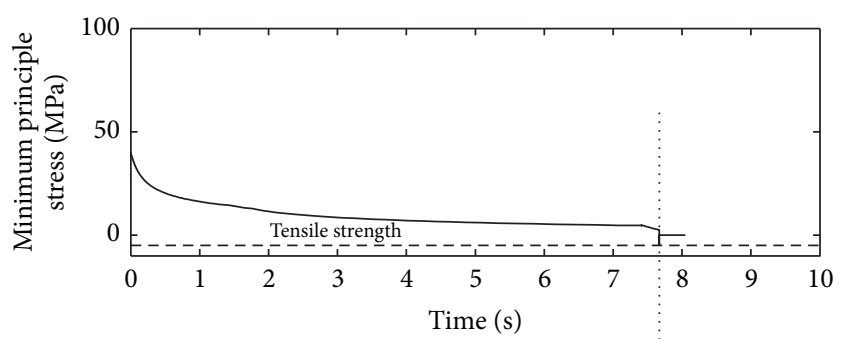

(a)

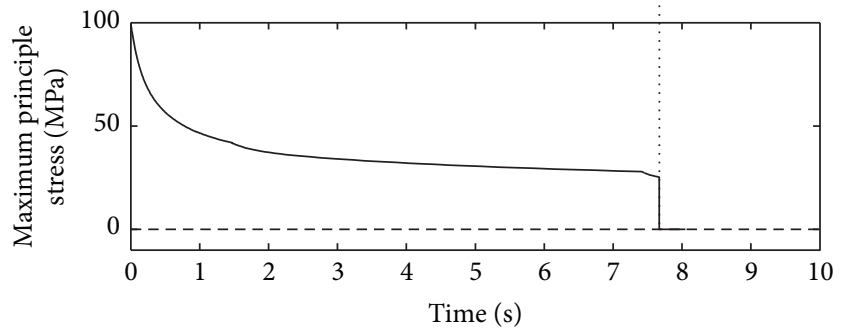

(b)

Figure 4: The stress evolution of the reference point in the numerical experiments: (a) the minimum principle stress; (b) the maximum principle stress. The stresses become zero when they reach the extension strength after 7.7 seconds.

up to $11 \mathrm{~mol} / \mathrm{kg}$ before yield and decreased to $7 \mathrm{~mol} / \mathrm{kg}$ after hydraulic fracturing.

Quartz is the main gauge mineral at the vein-type tungsten deposits [2]. Its dissolution and precipitation alter rock permeability and hence influence fluid flow and heat transfer in hydrothermal systems [80-85]. The predictive model proposed by Akinfiev and Diamond [86] was employed to calculate quartz solubility in aqueous $\mathrm{NaCl}$ solutions. Figure 7 shows that solubility of quartz in aqueous $\mathrm{NaCl}$ solutions 


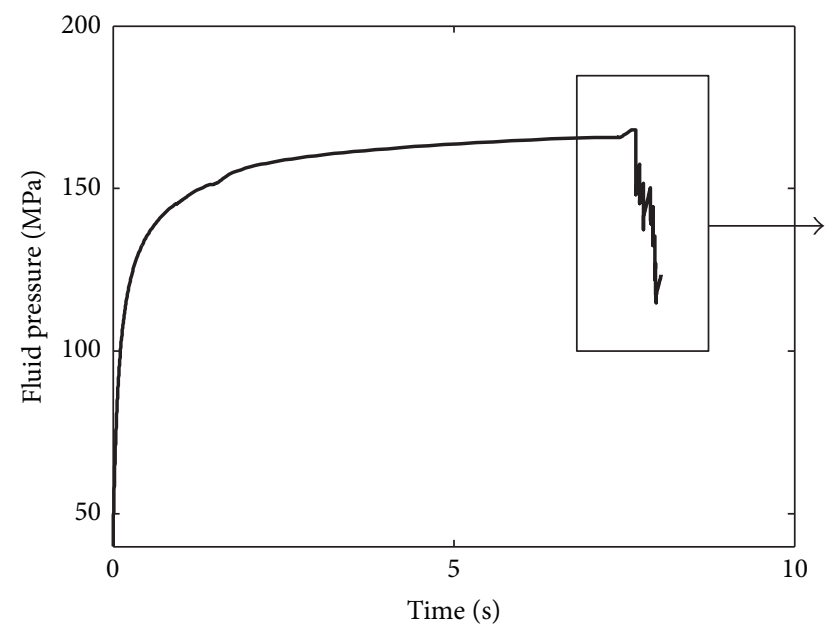

(a)

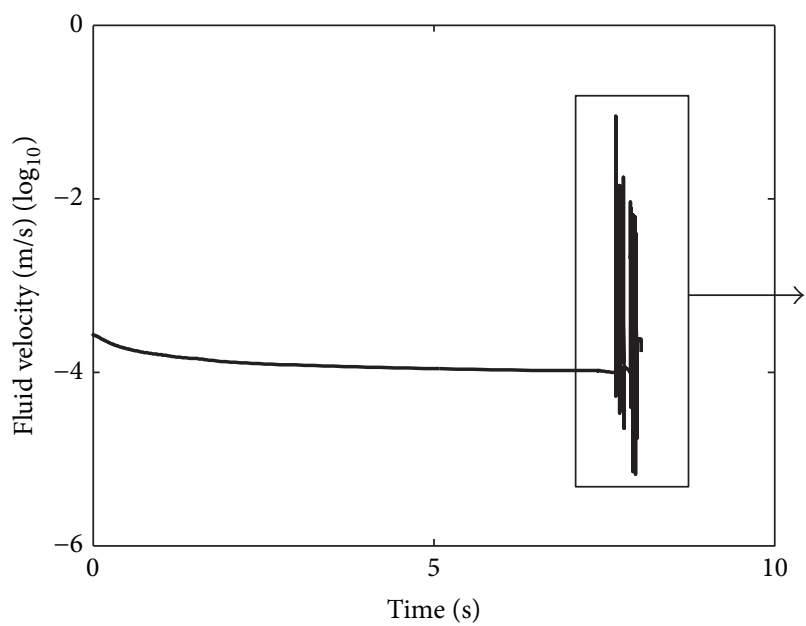

(c)

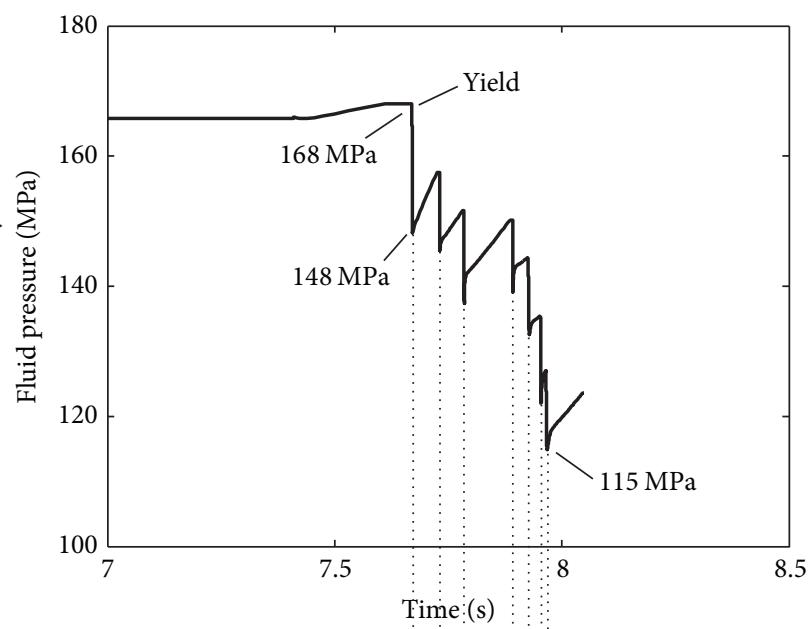

(b)

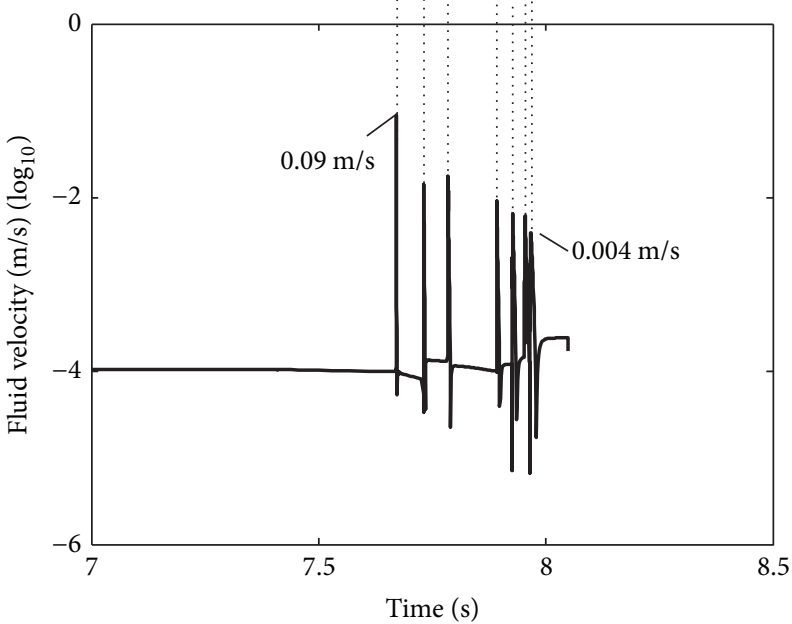

(d)

FIGURE 5: The fluid flow at the reference point in the numerical experiments: ((a), (b)) fluid pressure; ((c), (d)) fluid velocity.

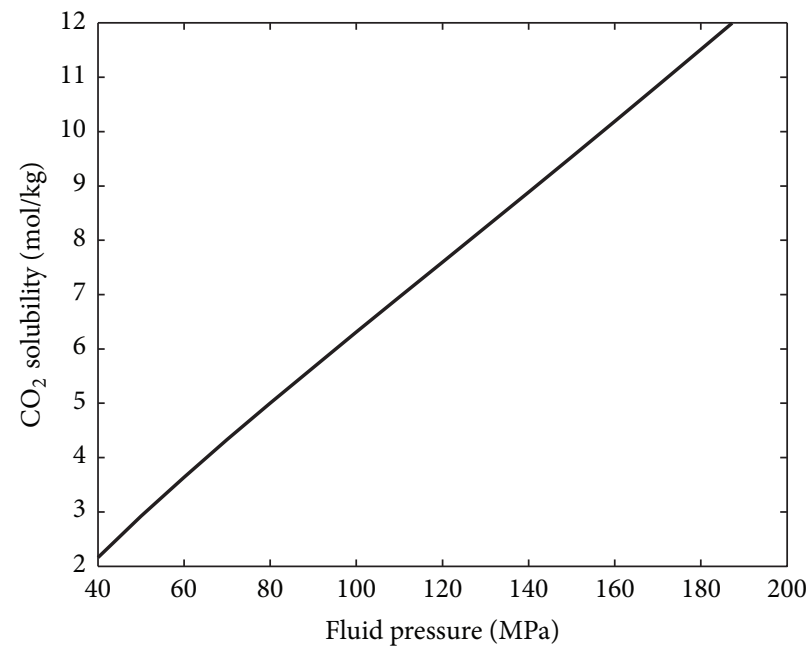

(a)

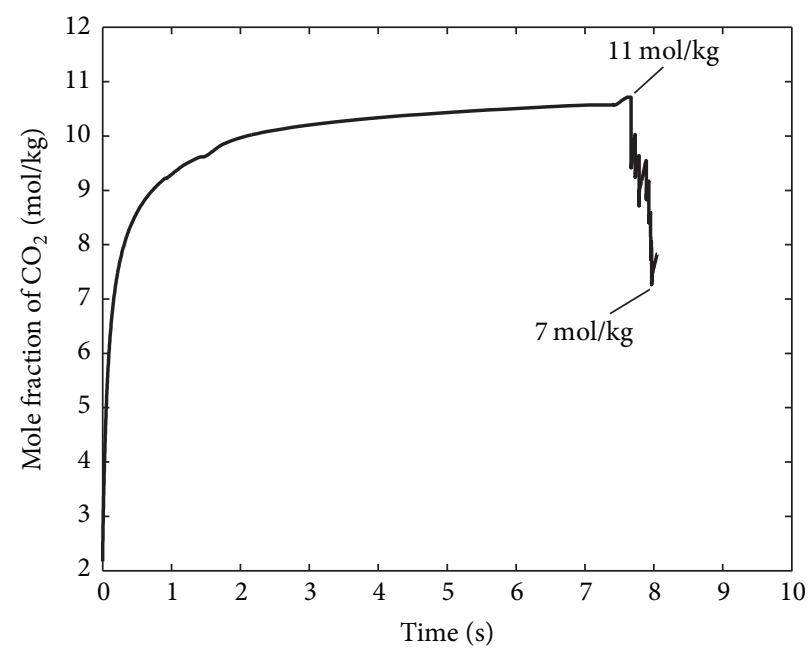

(b)

FIGURE 6: (a) $\mathrm{CO}_{2}$ solubility in aqueous $\mathrm{NaCl}$ solutions against fluid pressure at a temperature of $350^{\circ} \mathrm{C}$, reproduced from the solubility model in [79]; (b) the evolution of $\mathrm{CO}_{2}$ solubility at the reference point in the numerical experiments. 


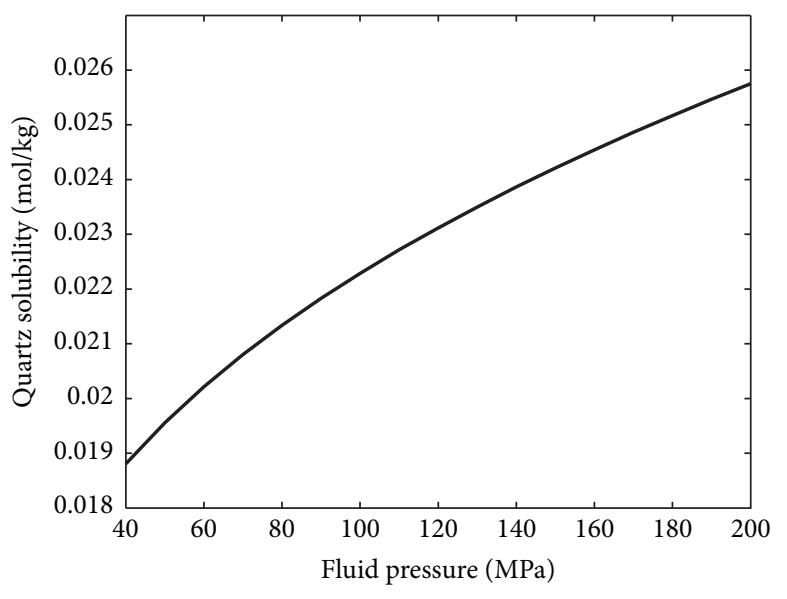

(a)

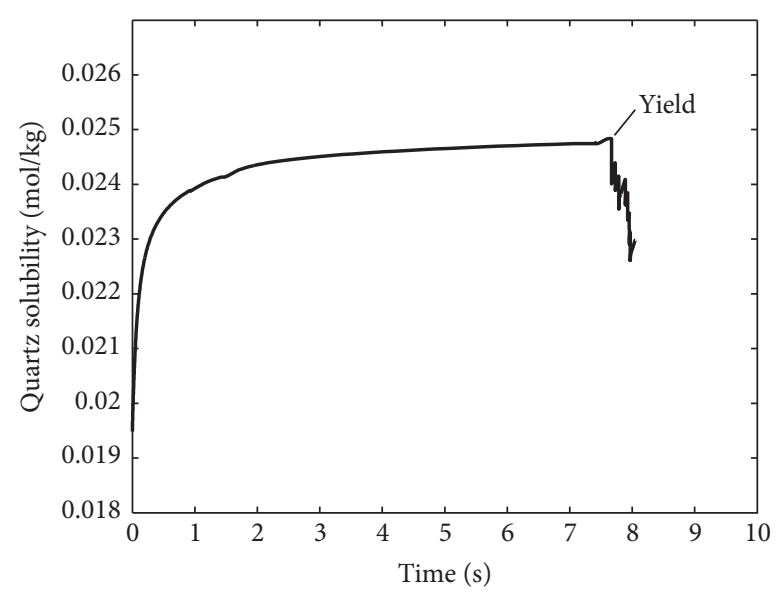

(b)

FIGURE 7: (a) Quartz solubility in aqueous $\mathrm{NaCl}$ solutions against fluid pressure at a temperature of $350^{\circ} \mathrm{C}$, reproduced from the solubility model in [87]; (b) the change of quartz solubility at the reference point in the numerical experiments.

increases with increasing fluid pressure. Quartz solubility decreased from $0.0248 \mathrm{~mol} / \mathrm{kg}$ to $0.0226 \mathrm{~mol} / \mathrm{kg}$ during hydraulic fracturing.

\section{Discussions}

5.1. Comparisons between Numerical Experiments and the Griffith Criterion. In the numerical experiments, extension failure forms when the minimum principle stress reaches the tensile strength and the differential stress is less than four times the tensile strength. This is consistent with the Griffith criterion for extension failure [88-90].

\subsection{Influences of Hydraulic Fracturing on Fluid Flow and Ore} Precipitation. In the numerical experiments, high-pressure fluids crack low-permeability rock and enhance its local permeability. This allows transient high-velocity hydrothermal flow. Such fluid pulses are also identified by other numerical models [22, 50, 52, 91, 92].

Quartz crystallization after fracture opening can decrease rock permeability and alter rock strength [87, 93-95]. In the numerical experiments, the quartz solubility decreases by $9 \%$ after hydraulic fracturing. This amount of quartz precipitation may be insufficient to decrease rock permeability significantly. Other factors like flow rate and supersaturation can be incorporated in further improvement of the models [96-98].

The fluid pressure and velocity fluctuate repeatedly once hydraulic fracturing occurs in the numerical experiments. This may promote chemical disequilibrium and cause mineral deposition reactions $[99,100]$. Tungsten solubility is weakly dependent on fluid pressure [38]. However, the fluid pressure drop during a hydraulic fracturing process decreases $\mathrm{CO}_{2}$ solubility significantly. This could cause effervescence of $\mathrm{CO}_{2}$ and increase $\mathrm{pH}$ and facilitate precipitation of ores like wolframite and cassiterite [37, 101-109]. Therefore, fluid pressure drop accompanying hydraulic fracturing is a trigger for increasing $\mathrm{pH}$ and could cause wolframite precipitation at tungsten deposits in the Nanling Range. Wood and Samson [38] do not consider the links of pressure drop to $\mathrm{CO}_{2}$ loss and further influence on tungsten solubility in their thermodynamic model. Our numerical experiments provide a supplement to their model.

Fluid immiscibility characterized by $\mathrm{CO}_{2}$ escaping is recorded by the fluid inclusions in quartz, beryl, and topaz at tungsten deposits in the Nanling Range $[6,10,11,76,77]$. However, evidence of fluid immiscibility has not yet been found in fluid inclusions in wolframite [3]. Phase separation of immiscible fluids in $\mathrm{NaCl}-\mathrm{H}_{2} \mathrm{O} \pm \mathrm{CO}_{2}$ systems is more difficult to occur at deeper levels than at shallower levels [110]. The relatively deep emplacement may be an important reason why phase separation is uncommon at the vein-type tungsten deposits in the Nanling Range [23].

Fluid mixing and simple cooling are also proposed to cause wolframite deposition at tungsten deposits in the Nanling Range $[3,9]$. It is recently reported that the irons contributed by the host rock are decisive for wolframite (dominantly $\mathrm{FeWO}_{4}$ ) precipitation at the Panasqueira deposit in Portugal [111]. These mechanisms for tungsten deposition do not contradict findings from the numerical experiments. Hydraulic fracturing cracks impermeable rocks and creates channels for later heat transfer and reactions between hydrothermal fluids and the host rock, which could last for a much longer timescale $[49,112]$. Our numerical experiments do not eliminate other possible mechanisms for wolframite precipitation at tungsten deposits in the Nanling Range.

\subsection{Hydraulic Fracturing and Emplacement Depth Estima-} tion. The fluid pressures recorded by fluid inclusions are commonly used to estimate the emplacement depth of ore deposits [113-116]. However, it is indefinite whether these pressures are lithostatic or hydrostatic [117]. Engelder [118] analyzed the links between fracture mechanics and fluid inclusion barometry. In the numerical experiments, the fixed pressure at the bottom is higher than the pressure recorded by fluid inclusions. The fluid pressures both before and 
after hydraulic fracturing are superlithostatic at the depth of $4 \mathrm{~km}$. Actually, hydraulic fracturing occurs because a pressure gradient changes the volume of a porous material and creates strains [43]. Thus, hydraulic fracturing depends on the initial stress field, the existence of faults, and the fluid pressure filed. The fluid pressure is very dynamic when coupled with rock deformation. Given that fluid inclusions may record some pressures after hydraulic fracturing, the fluid pressure fixed at the bottom of the model is higher than those recorded in fluid inclusion. Also, it requires some cautions before calculating the emplacement depth from the fluid pressures recorded by fluid inclusions. Combinations of refined models and fluid inclusion studies may offer better constraint on the emplacement depth of ore deposits.

\section{Conclusions}

The mechanisms precipitating wolframite is one of the most disputed issues on the ore forming processes at tungsten deposits in the Nanling Range. Previous studies for this focus on fluid inclusion and stable isotopic analysis but no one has yet evaluated the influences of mechanical processes on fluid flow and mineralization. Assuming fluid pressure is the only variable influencing solubility of $\mathrm{CO}_{2}$ and quartz, we investigate the influences of a hydraulic fracturing process on fluid flow and solubility of $\mathrm{CO}_{2}$ and quartz by using finite element-based numerical experiments. The numerical experiments provide the following implications for the mechanisms precipitating wolframite at tungsten deposits in the Nanling Range:

(1) Rock could be fractured by high-pressure fluids in a short time scale. Such a hydraulic fracturing is followed by significant fluctuations of fluid pressure and high-velocity hydrothermal pulse.

(2) The fluid pressure drop during the hydraulic fracturing process could result in a $9 \%$ decrease of quartz solubility. This amount of quartz crystallization may not cause a significant decrease in rock permeability.

(3) The fluid pressure decrease after hydraulic fracturing could reduce $\mathrm{CO}_{2}$ solubility by $36 \%$ and increases $\mathrm{pH}$. Because tungsten solubility is strongly negatively correlated to $\mathrm{pH}$, the fluid pressure drop accompanying hydraulic fracturing favours wolframite precipitation.

(4) The numerical experiments provide insight into the mechanisms precipitating wolframite at tungsten deposits in the Nanling Range as well as other metals whose solubility is strongly dependent on $\mathrm{pH}$.

\section{Conflicts of Interest}

The authors declare that they have no conflicts of interest.

\section{Acknowledgments}

The work is financially supported by the grants from National Natural Science Foundation of China (41602088 and 41373048), Australia Research Council (ARC DP150103467), and the MLR Nonprofit Industry Research Project
(201411024). The authors would like to thank Mao Shide for providing the code of $\mathrm{CO}_{2}$ solubility and Sun Rui for answering their queries. The numerical experiments were carried out by running the PANDAS software on the Savanna Supercomputer at The University of Queensland. The quartz solubility was calculated using the software LonerAP downloaded from http://fluids.unileoben.ac.at/Computer.html.

\section{References}

[1] M. Jingwen, C. Yanbo, C. Maohong, and F. Pirajno, "Major types and time-space distribution of Mesozoic ore deposits in South China and their geodynamic settings," Mineralium Deposita, vol. 48, no. 3, pp. 267-294, 2013.

[2] Y. C. Chen, R. F. Pei, H. L. Zhang et al., The Geology of Nonferrous and Rare Metal Deposits Related to Mesozoic Granitoids in Nanling Region, China, Geological Publishing Housing, Beijing, China, 1989.

[3] P. Ni, X.-D. Wang, G.-G. Wang, J.-B. Huang, J.-Y. Pan, and T.-G. Wang, "An infrared microthermometric study of fluid inclusions in coexisting quartz and wolframite from Late Mesozoic tungsten deposits in the Gannan metallogenic belt, South China," Ore Geology Reviews, vol. 65, no. 4, pp. 1062-1077, 2015.

[4] X. F. Cao, X. B. Lu, M. C. He, H. Niu, B. F. Du, and W. Mei, "An infrared microscope investigation of fluid inclusions in coexisting quartz and wolframite: a case study of Yaogangxian quartz vein wolframite deposit," Mineral Deposits, vol. 28, no. 5, pp. 611-620, 2009.

[5] X. D. Wang, P. Ni, S. D. Yuan, and S. H. Wu, "Fluid inclusion studies on coexisting cassiterite and quartz from the Piaotang tungsten deposit, Jiangxi Province, China," Acta Geologica Sinica, vol. 87, no. 6, pp. 850-859, 2013 (Chinese).

[6] B. B. Xi, D. H. Zhang, L. M. Zhou, W. H. Zhang, and C. Wang, "Characteristics of ore-forming fluid evolution in Dajishan tungsten deposit, Quannan County, Jiangxi," Acta Geologica Sinica, vol. 82, no. 7, pp. 956-966, 2008.

[7] Z. G. Mu, F. S. Huang, and C. Y. Chen, "Oxygen, hydrogen and carbon isotope studies of Piantang and Xihuasha quartz vein-type tungsten deposits, Jiangxi Province," in Proceedings of the Symposium on Tungsten Geology, Nanchang, pp. 153-168, Geological Publishing House, 1981.

[8] G. X. Zhang, Y. N. Xie, F. J. Yu, and H. B. Zhang, "Stable isotope geochemistry of distinct metallogenic stages of tungsten deposits in Dajishan mine, Jiangxi," Acta Geoscientica Sinica, vol. 18, pp. 197-199, 1997.

[9] W. Wei, R. Hu, X. Bi et al., "Infrared microthermometric and stable isotopic study of fluid inclusions in wolframite at the Xihuashan tungsten deposit, Jiangxi province, China," Mineralium Deposita, vol. 47, no. 6, pp. 589-605, 2012.

[10] Y. Q. Xiong, Y. J. Shao, H. D. Zhou et al., "Ore-forming mechanism of quartz-vein-type W-Sn deposits of the Xitian district in SE China: Implications from the trace element analysis of wolframite and investigation of fluid inclusions," Ore Geology Reviews, vol. 83, pp. 152-173, 2017.

[11] D. Q. Hu, R. M. Hua, G. L. Li, X. L. Wei, and X. E. Huang, "Study on the fluid inclusions of maoping tungsten deposit, Southern Jiangxi province," Geological Journal of China Universities, vol. 17, no. 2, pp. 327-336, 2011.

[12] S. E. Ingebritsen and M. S. Appold, "The physical hydrogeology of ore deposits," Economic Geology, vol. 107, no. 4, pp. 559-584, 2012. 
[13] S. E. Ingebritsen, S. Geiger, S. Hurwitz, and T. Driesner, "Numerical simulation of magmatic hydrothermal systems," Reviews of Geophysics, vol. 48, no. 1, Article ID RG1002, 2010.

[14] D. O. Hayba and S. E. Ingebritsen, "Multiphase groundwater flow near cooling plutons," Journal of Geophysical Research: Solid Earth, vol. 102, no. 6, pp. 12235-12252, 1997.

[15] C. W. Burnham, "Energy release in subvolcanic environments; implications for breccia formation," Economic Geology, vol. 80, no. 6, pp. 1515-1522, 1985.

[16] R. B. Hanson, "The hydrodynamics of contact metamorphism," Geological Society of America Bulletin, vol. 107, no. 5, pp. 595-611, 1995.

[17] S. R. Titley, "Evolution and Style of Fracture Permeability in Intrusion-Centered Hydrothermal Systems," in The Role of Fluids in Crustal Processes, J. D. Bredehoeft and D. L. Norton, Eds., The National Academies Press, Washington, DC, USA, 1990.

[18] H. Shinohara and K. Kazahaya, "Degassing Processes Related to Magma-Chamber Crystallization," in Short Course Series: Magmas, Fluids, and Ore Deposits, vol. 23, pp. 47-70, Mineralogical Association of Canada, Victoria, British Columbia, Canada, 1995.

[19] P. Weis, T. Driesner, and C. A. Heinrich, "Porphyry-copper ore shells form at stable pressure-temperature fronts within dynamic fluid plumes," Science, vol. 338, no. 6114, pp. 1613-1616, 2012.

[20] C. Halls, "Energy and Mechanism in the Magmato-Hydrothermal Evolution of the Cornubian Batholith: A Review," in Metallogeny of Collisional Oogens, R. Seltmann, H. Kampf, and P. Moller, Eds., pp. 274-294, Czech Geological Survey, Prague, Czech Republic, 1994.

[21] R. O. Fournier, "Hydrothermal processes related to movement of fluid from plastic into brittle rock in the magmatic-epithermal environment," Economic Geology, vol. 94, no. 8, pp. 11931211, 1999.

[22] S. F. Cox, "Injection-driven swarm seismicity and permeability enhancement: Implications for the dynamics of hydrothermal ore systems in high fluid-flux, overpressured faulting regimes-An invited paper," Economic Geology, vol. 111, no. 3, pp. 559-587, 2016.

[23] D. Wang, H. Lu, and X. Bi, "Comparison of characteristics of ore forming fluids between quartz-vein tungsten deposits and porphyry copper deposits associated with granitic rocks," Earth Science Frontiers, vol. 18, no. 5, pp. 121-131, 2011.

[24] Q. Wang, R. Hu, J. Peng et al., "Characteristics and significance of the fluid inclusions from Yaogangxian tungsten deposit in south of Hunan," Acta Petrologica Sinica, vol. 23, no. 9, pp. 22632273, 2007.

[25] X. M. Zhou, T. Sun, W. Z. Shen, L. S. Shu, and Y. L. Niu, "Petrogenesis of Mesozoic granitoids and volcanic rocks in South China: a response to tectonic evolution," Episodes, vol. 29, no. 1, pp. 26-33, 2006.

[26] R. Hua, P. Chen, W. Zhang et al., "Metallogenic systems related to Mesozoic and Cenozoic granitoids in South China," Science in China Series D: Earth Sciences, vol. 46, no. 8, pp. 816-829, 2003.

[27] X. Zhu, J. Wang, Y. Wang et al., "Characteristics of alkali feldspar granite in tungsten (tin) deposits of Nanling region," Geology in China, vol. 39, no. 2, pp. 359-371, 2012.

[28] X. Liu, H. Xing, and D. Zhang, "Fluid focusing and its link to vertical morphological zonation at the Dajishan vein-type tungsten deposit, South China," Ore Geology Reviews, vol. 62, no. 1, pp. 245-258, 2014.
[29] X. Zhu, J. Wang, Y. Wang, X. Chen, and Q. Fu, "Relatively closed ore-forming systems in the tungsten-bearing vein: a case study of the Yaogangxian deposit, Hunan Province," Acta Geologica Sinica, vol. 88, no. 5, pp. 825-835, 2014 (Chinese).

[30] X. Gong, G. Yan, T. Ye et al., "A Study of Ore-forming Fluids in the Shimensi Tungsten Deposit, Dahutang Tungsten Polymetallic Ore Field, Jiangxi Province, China," Acta Geologica Sinica, vol. 89, no. 3, pp. 822-835, 2015.

[31] J. Liu, J. Mao, H. Ye, and W. Zhang, "Geology, geochemistry and age of the Hukeng tungsten deposit, Southern China," Ore Geology Reviews, vol. 43, no. 1, pp. 50-61, 2011.

[32] X. Y. Zhu, J. B. Wang, Y. L. Wang, X. Y. Chen, F. U. Qibin, and Y. Tian, "The differences of the ore-forming fluid between the vein-type and skarn type tungsten deposits," Acta Petrologica Sinica, vol. 31, no. 4, pp. 941-953, 2015 (Chinese).

[33] H. L. Huang, H. L. Chang, J. Tan, F. Li, C. H. Zhang, and Y. Zhou, "Contrasting infrared microthermometry study of fluid inclusions in coexisting quartz, wolframite and others minerals: A case study of Xihuashan quartz-vein tungsten deposit," Acta Petrologica Sinica, vol. 31, no. 4, pp. 925-940, 2015.

[34] S. He and X. Xi, "The genesis of the en-echelon structure of tungsten veins in Xihuashan, Jiangxi," Acta Geologica Sinica, vol. 1, no. 1, pp. 31-42, 1988 (Chinese).

[35] J. Xu, Z. Zeng, D. Wang et al., "A new type of tungsten deposit in southern Jiangxi and the new model of 'five floors + basement' for prospecting," Acta Geologica Sinica, vol. 82, no. 7, pp. 880887, 2008 (Chinese).

[36] C. Yu, "Fractal dilation of multiple hydraulic fracturing," Earth Science Frontiers, vol. 11, no. 3, pp. 11-44, 2004.

[37] D. A. Polya, "Pressure-Independence of Wolframite solubility for Hydrothermal Vein Formation," Transactions of the Institution of Mining and Metellurgy, vol. 99, no. B59, pp. 120-124, 1990.

[38] S. A. Wood and I. M. Samson, "The hydrothermal geochemistry of tungsten in granitoid environments: I. Relative solubilities of ferberite and scheelite as a function of $\mathrm{T}, \mathrm{P}, \mathrm{pH}$, and $M_{\text {nacl }}$," Economic Geology, vol. 95, no. 1, pp. 143-182, 2000.

[39] M. K. Hubbert and D. G. Willis, "Mechanics of hydraulic fracturing," Transactions of Society of Petroleum Engineers of AIME, vol. 210, pp. 153-168, 1972.

[40] R. J. Davies, S. A. Mathias, J. Moss, S. Hustoft, and L. Newport, "Hydraulic fractures: How far can they go?" Marine and Petroleum Geology, vol. 37, no. 1, pp. 1-6, 2012.

[41] M. K. Fisher and N. R. Warpinski, "Hydraulic Fracture-Height Growth: Real Data," in Proceedings of the SPE Annual Technical Conference and Exhibition, pp. 1-19, Denver, Colo, USA, October 2011.

[42] X. Luo and G. Vasseur, "Natural hydraulic cracking: Numerical model and sensitivity study," Earth and Planetary Science Letters, vol. 201, no. 2, pp. 431-446, 2002.

[43] H. F. Wang, "Theory of linear poroelasticity," in Princeton Series in Geophysics, p. 287, Princeton University Press, Princeton, NJ, USA, 2000.

[44] A. Barnhoorn, S. F. Cox, D. J. Robinson, and T. Senden, "Stressand fluid-driven failure during fracture array growth: Implications for coupled deformation and fluid flow in the crust," Geology, vol. 38, no. 9, pp. 779-782, 2010.

[45] S. F. Cox, "Structural and isotopic constraints on fluid flow regimes and fluid pathways during upper crustal deformation: An example from the Taemas area of the Lachlan Orogen, SE Australia," Journal of Geophysical Research: Solid Earth, vol. 112, no. 8, Article ID B08208, 2007. 
[46] P. D. Bons, "The formation of large quartz veins by rapid ascent of fluids in mobile hydrofractures," Tectonophysics, vol. 336, no. 1-4, pp. 1-17, 2001.

[47] P. D. Bons and B. P. van Milligen, "New experiment to model self-organized critical transport and accumulation of melt and hydrocarbons from their source rocks," Geology, vol. 29, no. 10, pp. 919-922, 2001.

[48] S. A. Miller and A. Nur, "Permeability as a toggle switch in fluid-controlled crustal processes," Earth and Planetary Science Letters, vol. 183, no. 1-2, pp. 133-146, 2000.

[49] L. M. Cathles and R. Shannon, "How potassium silicate alteration suggests the formation of porphyry ore deposits begins with the nearly explosive but barren expulsion of large volumes of magmatic water," Earth and Planetary Science Letters, vol. 262, no. 1-2, pp. 92-108, 2007.

[50] T. Sachau, P. D. Bons, and E. Gomez-Rivas, "Transport efficiency and dynamics of hydraulic fracture networks," Frontiers in Physics, vol. 3, 2015.

[51] P. Weis, "The dynamic interplay between saline fluid flow and rock permeability in magmatic-hydrothermal systems," Geofluids, vol. 15, no. 1-2, pp. 350-371, 2015.

[52] M. Lupi, S. Geiger, and C. M. Graham, "Numerical simulations of seismicity-induced fluid flow in the Tjörnes Fracture Zone, Iceland," Journal of Geophysical Research: Solid Earth, vol. 116, no. B7, Article ID B07101, 2011.

[53] A. Beach, "Numerical models of hydraulic fracturing and the interpretation of syntectonic veins," Journal of Structural Geo$\log y$, vol. 2, no. 4, pp. 425-438, 1980.

[54] S. A. Rojstaczer, S. E. Ingebritsen, and D. O. Hayba, "Permeability of continental crust influenced by internal and external forcing," Geofluids, vol. 8, no. 2, pp. 128-139, 2008.

[55] P. I. Nabelek, "Numerical simulation of kinetically-controlled calc-silicate reactions and fluid flow with transient permeability around crystallizing plutons," American Journal of Science, vol. 309, no. 7, pp. 517-548, 2009.

[56] X. Cui, P. I. Nabelek, and M. Liu, "Heat and fluid flow in contact metamorphic aureoles with layered and transient permeability, with application to the Notch Peak aureole, Utah," Journal of Geophysical Research: Solid Earth, vol. 106, no. B4, pp. 64776491, 2001.

[57] C. E. Neuzil, "Hydromechanical coupling in geologic processes," Hydrogeology Journal, vol. 11, no. 1, pp. 41-83, 2003.

[58] H. L. Xing and A. Makinouchi, "Three dimensional finite element modeling of thermomechanical frictional contact between finite deformation bodies using R-minimum strategy," Computer Methods in Applied Mechanics and Engineering, vol. 191, no. 37-38, pp. 4193-4214, 2002.

[59] H. L. Xing, A. Makinouchi, and P. Mora, "Finite element modeling of interacting fault systems," Physics of the Earth and Planetary Interiors, vol. 163, no. 1-4, pp. 106-121, 2007.

[60] H. Xing, "Finite element simulation of transient geothermal flow in extremely heterogeneous fractured porous media," Journal of Geochemical Exploration, vol. 144, pp. 168-178, 2014.

[61] Q. Li and H. Xing, "Numerical analysis of the material parameter effects on the initiation of hydraulic fracture in a near wellbore region," Journal of Natural Gas Science and Engineering, vol. 27, Part 3, pp. 1597-1608, 2015.

[62] X. Liu, H. Xing, and D. Zhang, "The mechanisms of the infill textures and its implications for the five-floor zonation at the Dajishan vein-type tungsten deposit, China," Ore Geology Reviews, vol. 65, Part 1, pp. 365-374, 2015.
[63] Q. Li and H. Xing, "A new method for determining the equivalent permeability of a cleat dominated coal sample," Journal of Natural Gas Science and Engineering, vol. 34, pp. 280-290, 2016.

[64] X. Liu, H. Xing, and D. Zhang, "Influences of fluid properties on the hydrothermal fluid flow and alteration halos at the Dajishan tungsten deposit, China," Journal of Geochemical Exploration, vol. 163, pp. 53-69, 2016.

[65] H. Xing, Y. Liu, J. Gao, and S. Chen, "Recent development in numerical simulation of enhanced geothermal reservoirs," Journal of Earth Science, vol. 26, no. 1, pp. 28-36, 2015.

[66] M.-H. Yu, "Advances in strength theories for materials under complex stress state in the 20th century," Applied Mechanics Reviews, vol. 55, no. 3, pp. 169-218, 2002.

[67] R. H. Sibson, "Seismogenic framework for hydrothermal transport and ore deposition," Reviews in Economic Geology, vol. 14, pp. 25-50, 2001.

[68] C. Zhao, L. B. Reid, and K. Regenauer-Lieb, "Some fundamental issues in computational hydrodynamics of mineralization: a review," Journal of Geochemical Exploration, vol. 112, pp. 21-34, 2012.

[69] D. A. Singer, I. Vladimir, and B. C. Moring, "Porphyry Copper Deposits of the World: Database and Grade and Tonnage Models, 2008," Tech. Rep. Open-File Report 2008-1155, U.S. Geological Survey, 2008.

[70] M. S. Sams and A. Thomas-Betts, "Models of convective fluid flow and mineralization in south-west England," Journal of the Geological Society, vol. 145, no. 5, pp. 809-817, 1988.

[71] T. Baker, P. J. Pollard, R. Mustard, G. Mark, and J. L. Graham, "A comparison of granite-related tin, tungsten and gold-bismuth deposits: implications for exploration," Society of Economic Geologists Newsletter, vol. 61, pp. 5-17, 2005.

[72] J. P. Spivey, W. D. McCain Jr., and R. North, "Estimating density, formation volume factor, compressibility, methane solubility, and viscosity for oilfield brines at temperatures from 0 to $275^{\circ} \mathrm{C}$, pressures to $200 \mathrm{MPa}$, and salinities to $5.7 \mathrm{~mole} / \mathrm{kg}$," Journal of Canadian Petroleum Technology, vol. 43, no. 7, pp. 52-61, 2004.

[73] Y. D. Li, "Poly-Type Model for Tungsten Deposits and Vertical Structural Zoning Model for Vein-Type Tungsten Deposits in South China," in Mineral Deposit Modeling, R. V. Kirkham, W. D. Sinclair, R. I. Thorpe, and J. M. Duke, Eds., vol. 40, Special Paper 40, pp. 555-568, Geological Association of Canada, Newfoundland and Labrador, Canada, 1993.

[74] R. Q. Zhang, J. J. Lu, B. Lehmann et al., "Combined zircon and cassiterite $\mathrm{U}-\mathrm{Pb}$ dating of the Piaotang granite-related tungsten-tin deposit, southern Jiangxi tungsten district, China," Ore Geology Reviews, vol. 82, pp. 268-284, 2017.

[75] D. A. Lockner, "Rock failure," Rock Physics \& Phase Relations: A Handbook of Physical Constants, pp. 127-147, 1995.

[76] X. D. Wang, P. Ni, S. D. Yuan, and S. H. Wu, "Fluid inclusion studies of Dajishan tungsten deposit in Jiangxi Province," Mineral Deposits, vol. 32, pp. 308-322, 2013.

[77] B. Zhao, A study on metallogenic depth of Piaotang quartz vein type wolframite deposit in Jiangxi Province [M.S. thesis], China University of Geosciences, Beijing, China, 2013.

[78] H. L. Huang, H. L. Chang, F. Li et al., "Microthermometry and characteristic element determination for the fluid inclusions in the wolframite and quartz in the drusy cavities of Xihuanshan tungsten deposit," Earth Science Frontiers, vol. 20, no. 2, pp. 205212, 2013. 
[79] S. Mao, D. Zhang, Y. Li, and N. Liu, "An improved model for calculating $\mathrm{CO}_{2}$ solubility in aqueous $\mathrm{NaCl}$ solutions and the application to $\mathrm{CO}_{2}-\mathrm{H}_{2} \mathrm{O}-\mathrm{NaCl}$ fluid inclusions," Chemical Geo$\log y$, vol. 347, pp. 43-58, 2013.

[80] J. Yang, "Reactive silica transport in fractured porous media: Analytical solutions for a system of parallel fractures," Journal of Geophysical Research: Solid Earth, vol. 117, no. B4, Article ID B04106, 2012.

[81] D. E. Dempsey, J. V. Rowland, G. A. Zyvoloski, and R. A. Archer, "Modeling the effects of silica deposition and fault rupture on natural geothermal systems," Journal of Geophysical Research: Solid Earth, vol. 117, no. B5, Article ID B05207, 2012.

[82] B. L. Dutrow, B. J. Travis, C. W. Gable, and D. J. Henry, "Coupled heat and silica transport associated with dike intrusion into sedimentary rock: Effects on isotherm location and permeability evolution," Geochimica et Cosmochimica Acta, vol. 65, no. 21, pp. 3749-3767, 2001.

[83] A. Ghassemi and G. Suresh Kumar, "Changes in fracture aperture and fluid pressure due to thermal stress and silica dissolution/precipitation induced by heat extraction from subsurface rocks," Geothermics, vol. 36, no. 2, pp. 115-140, 2007.

[84] M. Steele-MacInnis, L. Han, R. P. Lowell, J. D. Rimstidt, and R. J. Bodnar, "The role of fluid phase immiscibility in quartz dissolution and precipitation in sub-seafloor hydrothermal systems," Earth and Planetary Science Letters, vol. 321-322, pp. 139-151, 2012.

[85] J. T. Martin and R. P. Lowell, "Precipitation of quartz during high-temperature, fracture-controlled hydrothermal upflow at ocean ridges: Equilibrium versus linear kinetics," Journal of Geophysical Research: Solid Earth, vol. 105, no. B1, pp. 869-882, 2000.

[86] N. N. Akinfiev and L. W. Diamond, "A simple predictive model of quartz solubility in water-salt- $\mathrm{CO}_{2}$ systems at temperatures up to $1000^{\circ} \mathrm{C}$ and pressures up to $1000 \mathrm{MPa}$," Geochimica et Cosmochimica Acta, vol. 73, no. 6, pp. 1597-1608, 2009.

[87] J. T. Martin and R. P. Lowell, "On thermoelasticity and silica precipitation in hydrothermal systems: Numerical modeling of laboratory experiments," Journal of Geophysical Research: Solid Earth, vol. 102, no. B6, pp. 12095-12107, 1997.

[88] S. F. Cox, "The application of failure mode diagrams for exploring the roles of fluid pressure and stress states in controlling styles of fracture-controlled permeability enhancement in faults and shear zones," Geofluids, vol. 10, no. 1-2, pp. 217-233, 2010.

[89] R. H. Sibson, "Controls on maximum fluid overpressure defining conditions for mesozonal mineralisation," Journal of Structural Geology, vol. 26, no. 6-7, pp. 1127-1136, 2004.

[90] J. W. Cosgrove, "The expression of hydraulic fracturing in rocks and sediments," Geological Society Special Publication, vol. 92, pp. 187-196, 1995.

[91] N. H. S. Oliver, "Linking of regional and local hydrothermal systems in the mid-crust by shearing and faulting," Tectonophysics, vol. 335, no. 1-2, pp. 147-161, 2001.

[92] A. Okamoto and N. Tsuchiya, "Velocity of vertical fluid ascent within vein-forming fractures," Geology, vol. 37, no. 6, pp. 563$566,2009$.

[93] R. P. Lowell, P. Van Cappellen, and L. N. Germanovich, "Silica precipitation in fractures and the evolution of permeability in hydrothermal upflow zones," Science, vol. 260, no. 5105, pp. 192194, 1993.

[94] S. B. Giger, E. Tenthorey, S. F. Cox, and J. D. Fitz Gerald, "Permeability evolution in quartz fault gouges under hydrothermal conditions," Journal of Geophysical Research: Solid Earth, vol. 112, no. B7, Article ID B07202, 2007.

[95] E. Tenthorey and S. F. Cox, "Cohesive strengthening of fault zones during the interseismic period: An experimental study," Journal of Geophysical Research: Solid Earth, vol. 111, no. B9, Article ID B09202, 2006.

[96] C. Hilgers, K. Dilg-Gruschinski, and J. L. Urai, "Microstructural evolution of syntaxial veins formed by advective flow," Geology, vol. 32, no. 3, pp. 261-264, 2004.

[97] S. Nollet, C. Hilgers, and J. L. Urai, "Experimental study of polycrystal growth from an advecting supersaturated fluid in a model fracture," Geofluids, vol. 6, no. 2, pp. 185-200, 2006.

[98] R. H. Lander and S. E. Laubach, "Insights into rates of fracture growth and sealing from a model for quartz cementation in fractured sandstones," Bulletin of the Geological Society of America, vol. 127, no. 3-4, pp. 516-538, 2014.

[99] A. Ord, B. E. Hobbs, and D. R. Lester, "The mechanics of hydrothermal systems: I. Ore systems as chemical reactors," Ore Geology Reviews, vol. 49, pp. 1-44, 2012.

[100] D. R. Lester, A. Ord, and B. E. Hobbs, "The mechanics of hydrothermal systems: II. Fluid mixing and chemical reactions," Ore Geology Reviews, vol. 49, pp. 45-71, 2012.

[101] M. Ahmad, "The origin of tin deposits in the Mount Wells Region, Pine Creek Geosyncline, Northern Territory," Australian Journal of Earth Sciences, vol. 40, no. 5, pp. 427-443, 1993.

[102] N. C. Higgins, "Wolframite deposition in a hydrothermal vein system: the Grey River tungsten prospect, Newfoundland, Canada," Economic Geology, vol. 80, no. 5, pp. 1297-1327, 1985.

[103] R. R. Seal, A. H. Clark, and C. J. Morrissy, "Stockwork tungsten (scheelite)-molybdenum mineralization, Lake George, southwestern New Brunswick," Economic Geology, vol. 82, no. 5, pp. 1259-1282, 1987.

[104] Chil-Sup So and Seong-Taek Yun, "Origin and evolution of W-Mo-producing fluids in a granitic hydrothermal system; geochemical studies of quartz vein deposits around the Susan Granite, Hwanggangri District, Republic of Korea," Economic Geology, vol. 89, no. 2, pp. 246-267, 1994.

[105] J. V. G. Lynch, "Hydrothermal alteration, veining, and fluidinclusion characteristics of the Kalzas wolframite deposit, Yukon," Canadian Journal of Earth Sciences, vol. 26, no. 10, pp. 2106-2115, 1989.

[106] J. S. Bettencourt, W. B. Leite Jr., C. L. Goraieb, I. Sparrenberger, R. M. S. Bello, and B. L. Payolla, "Sn-polymetallic greisentype deposits associated with late-stage rapakivi granites, Brazil: Fluid inclusion and stable isotope characteristics," Lithos, vol. 80, no. 1-4, pp. 363-386, 2005.

[107] F. Pirajno, D. Phillips, and R. A. Armstrong, "Volcanology and eruptive histories of the Erongo volcanic complex and the Paresis igneous complex, Namibia: implications for mineral deposit styles," Communications of the Geological Survey of Namibia, vol. 12, pp. 301-312, 2000.

[108] F. Noronha, A. Doria, J. Dubessy, and B. Charoy, "Characterization and timing of the different types of fluids present in the barren and ore-veins of the W-Sn deposit of Panasqueira, Central Portugal," Mineralium Deposita, vol. 27, no. 1, pp. 7279, 1992.

[109] J. R. Taylor and V. J. Wall, "Cassiterite solubility, tin speciation, and transport in a magmatic aqueous phase," Economic Geology, vol. 88, no. 2, pp. 437-460, 1993.

[110] H. Z. Lu, "Fluid immiscibility and fluid inclusions," Acta Petrologica Sinica, vol. 27, no. 5, pp. 1253-1261, 2011. 
[111] P. Lecumberri-Sanchez, R. Vieira, C. Heinrich, F. Pinto, and M. Wälle, "Fluid-rock interaction is decisive for the formation of tungsten deposits," Geology, vol. 45, no. 7, pp. 579-582, 2017.

[112] S. Geiger, R. Haggerty, J. H. Dilles, M. H. Reed, and S. K. Matthäi, "New insights from reactive transport modelling: The formation of the sericitic vein envelopes during early hydrothermal alteration at Butte, Montana," Geofluids, vol. 2, no. 3, pp. 185-201, 2002.

[113] P. B. Redmond, M. T. Einaudi, E. E. Inan, M. R. Landtwing, and C. A. Heinrich, "Copper deposition by fluid cooling in intrusion-centered systems: New insights from the Bingham porphyry ore deposit, Utah," Geology, vol. 32, no. 3, pp. 217-220, 2004.

[114] R. L. Linnen, "Depth of emplacement, fluid provenance and metallogeny in granitic terranes: a comparison of western Thailand with other tin belts," Mineralium Deposita, vol. 33, no. 5, pp. 461-476, 1998.

[115] J. J. Wilkinson, "Fluid inclusions in hydrothermal ore deposits," Lithos, vol. 55, no. 1-4, pp. 229-272, 2001.

[116] E. Roedder and R. J. Bodnar, "Geologic pressure determinations from fluid inclusion studies," Annual Review of Earth and Planetary Sciences, vol. 8, no. 1, pp. 263-301, 1980.

[117] T. H. Hansteen and A. Klügel, "Fluid inclusion thermobarometry as a tracer for magmatic processes," Reviews in Mineralogy and Geochemistry, vol. 69, no. 1, pp. 143-177, 2008.

[118] T. Engelder, Stress Regimes in the Lithosphere, Princeton University Press, Princeton, NJ, USA, 1993. 

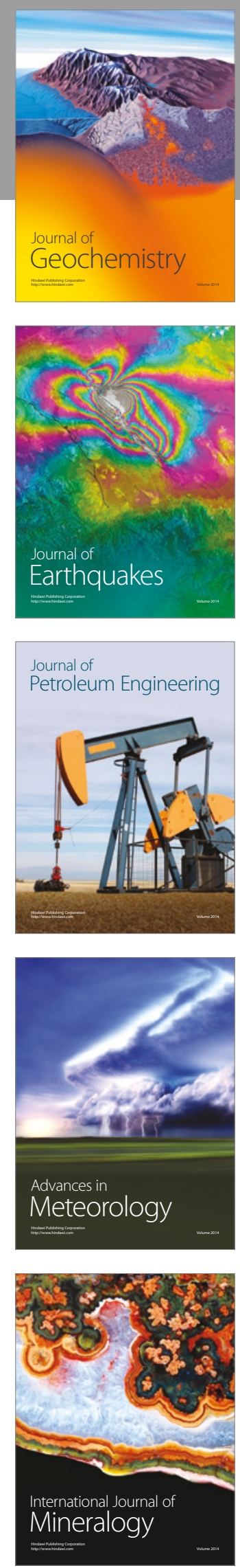
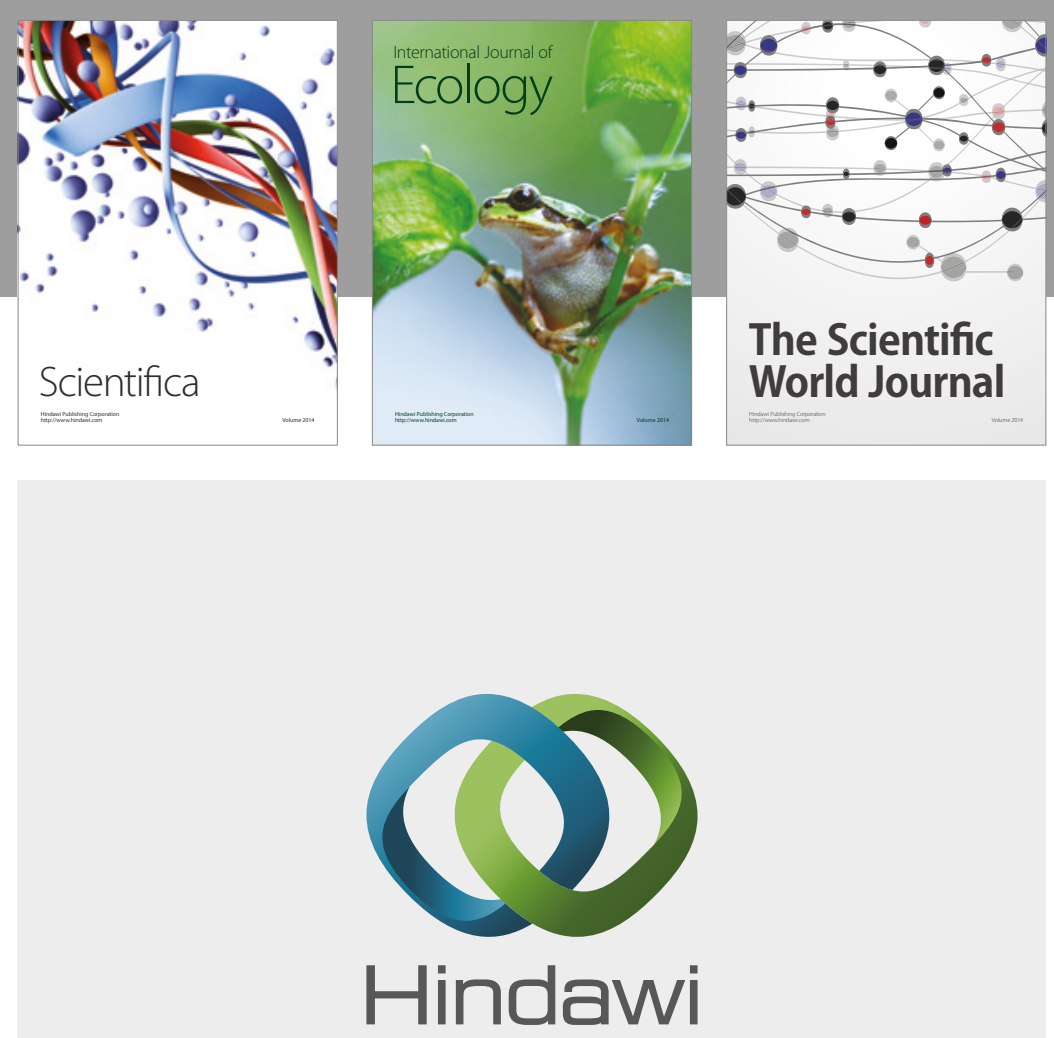

Submit your manuscripts at

https://www.hindawi.com
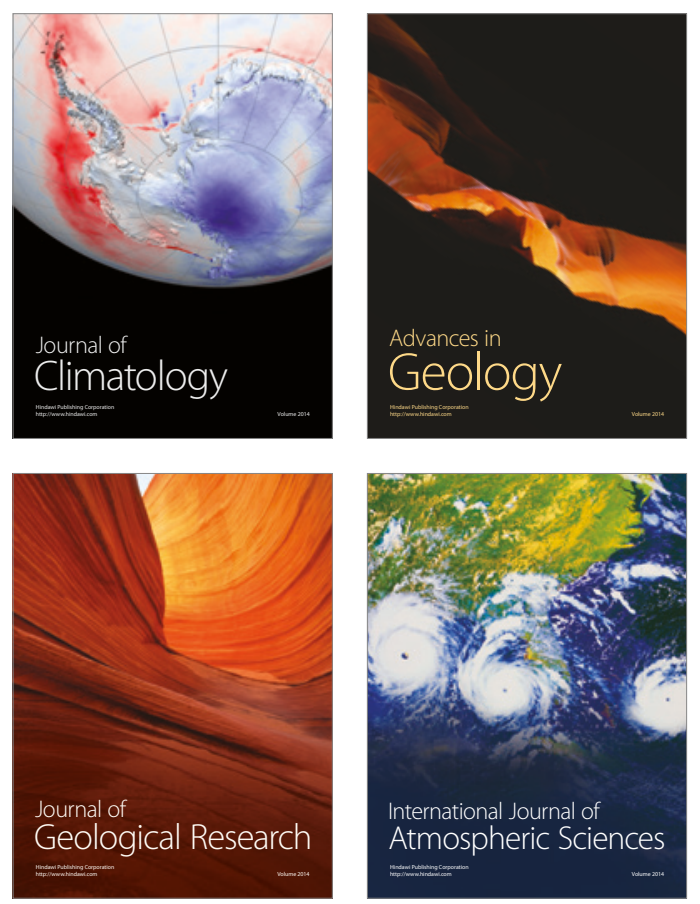

The Scientific

World Journal
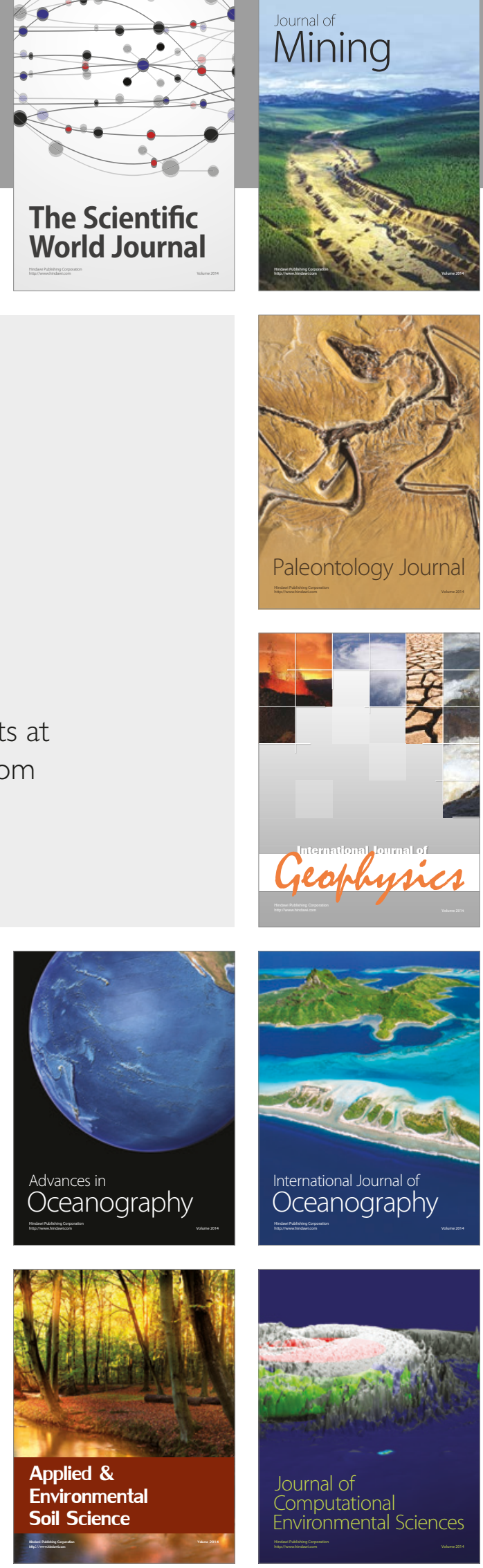